OPEN ACCESS

Edited by:

Gabrielle Wilcox,

University of Calgary, Canada

Reviewed by:

Anna K. Touloumakos,

Panteion University, Greece

Efthymios Papatzikis,

Oslo Metropolitan University, Norway

*Correspondence:

Finja Grospietsch

finja.grospietsch@uni-kassel.de

Specialty section:

This article was submitted to Educational Psychology,

a section of the journal

Frontiers in Education

Received: 08 February 2021 Accepted: 22 June 2021

Published: 21 July 2021

Citation:

Grospietsch F and Lins I (2021) Review on the Prevalence and Persistence of Neuromyths in Education - Where We

Stand and What is Still Needed.

Front. Educ. 6:665752.

doi: $10.3389 /$ feduc.2021.665752

\section{Review on the Prevalence and Persistence of Neuromyths in Education - Where We Stand and What Is Still Needed}

\section{Finja Grospietsch * and Isabelle Lins}

Department of Biology Education, University of Kassel, Kassel, Germany

The buzzword brain-based learning emerged in the 1970s and continues to fascinate teachers and learners in schools and universities today. However, what interested teachers often fail to realize is that brain-based or brain-friendly learning can not only be a plausible concept, but also a myth when applied incorrectly. Numerous empirical studies reveal a high degree of support for misconceptions about learning and the brain, known as neuromyths, among both pre-service and in-service teachers. When applied in the classroom, these myths can waste the educational system's money, time and effort. Even though the neuromyths issue has been known for two decades and the topic remains a focus of constant research, even today, the research discourse barely goes beyond replicating the earliest research findings. This review article provides an overview of the theoretical and empirical state of research on neuromyths. As part of this, ten neuromyths on the subject of learning and memory will be described in terms of content and the results of prior studies on neuromyths will be summarized. The overview of the theoretical and empirical state of research serves as a basis for highlighting controversies, fundamental concepts, issues and problems, current research gaps and potential developments in the field. Topics discussed include whether controversial research findings on correlations with endorsement of neuromyths are merely a methodological artefact, and why contradictions exist between the theoretical and empirical state of research. In addition, three central research gaps will be identified: First, studies should be conducted on whether and to what extent the endorsement of neuromyths really deprives teachers and students of opportunities to spend the education system's money, time and effort on more effective theories and methods. Second, there is too little work on developing and evaluating intervention approaches to combat neuromyths. Third, a standard scientific methodology or guidelines for determining new neuromyths are lacking. As desirable future developments in the field, more work educating people on neuromyths, uniform vocabulary, and interdisciplinary cooperation are highlighted. This contributes to answering the question of to what extent interweaving neuroscience, educational science and cognitive psychology can contribute to reducing the prevalence of neuromyths in education.

Keywords: neuromyths, neurodidactics, brain-based learning, brain-friendly learning, educational neuroscience, neuroeducation, MBE (mind, brain, and education science) 


\section{INTRODUCTION}

Insights from brain research have resulted in a downright neuroboom in recent years, expressed not only in transfer endeavors such as neuro-marketing, neuro-architecture and neuromanagement (Grospietsch and Mayer, 2020), but also and primarily in various neuro-education or neuro-didactics publications for teachers and learning guides for students (e.g., Jensen, 1998; Sprenger, 2002; Doyle and Zakrajsek, 2013; Kagan, 2014; Grospietsch, 2021). Brain-based or brain-friendly learning is often treated as a magic word in schools, universities and other educational institutions (e.g., Jensen, 2008; Folta-Schoofs and Ostermann, 2019). "Brain-based learning can change everything", "Brain-friendly learning is a little gear that, when turned, unleashes a powerful effect", and "When we teach children and youth how to learn in a brain-friendly way, we change the world" are just a few of the promises made with respect to neurodidactics. However, interested teachers and learners often fail to consider that neurodidactics is more than just a plausible concept - it can also be a myth when applied incorrectly. For example, the promises above often go along with recommendations such as "Our brain wants us to use all of it and not just a small fraction", "Address both brain hemispheres in equal measure", or "Pay attention to whether you are a visual, auditory or haptic learner". From a scientific perspective, so-called neuromyths can be found at the core of these deceptively simple recommendations (Organisation for Economic Co-operation and Development [OECD], 2002). Numerous empirical studies reveal widespread endorsement of such misconceptions on the topic of learning and the brain both among the public at large and among pre-service and in-service teachers (e.g., Dekker et al., 2012; Ferrero et al., 2016). Even school principals, awardwinning teachers and university instructors widely endorse neuromyths like "we only use 10\% of our brains", "learning differences due to hemispheric use", or the "existence of learning styles" (Horvath et al., 2018; Zhang et al., 2019). On the one hand, this is problematic because it could lead teachers to pass on incorrect content and/or ineffective learning strategies to their students. On the other hand, it could waste the education system's "money, time and effort" (Dekker et al., 2012, p. 1) and deprive both teachers and learners of opportunities to expend resources on more effective theories and methods (e.g., teaching learning strategies or cognitive activation). This review article provides an overview of the theoretical and empirical state of research on neuromyths ${ }^{1}$ und discusses controversies, fundamental concepts, issues and problems, current research gaps and potential developments in the field. It also seeks to gain insight into the question of to what extent interweaving neuroscience, educational science and cognitive psychology can contribute to reducing the prevalence of neuromyths in education.

\footnotetext{
${ }^{1}$ Articles involving theoretical descriptions of individual neuromyths and/or studies presenting empirical results are included. More general contributions on neuromyths (Papatzikis, 2017; Pasquinelli, 2012; Purdy, 2008; etc.) are excluded since this review aims at a closer focus on the topic.
}

\section{THEORETICAL STATE OF RESEARCH ON NEUROMYTHS}

The term "neuromyth" was coined by the neurosurgeon Alan Crockard in the 1980s to describe scientifically inaccurate understandings of the brain in medical culture (Howard-Jones, 2010). The Organisation for Economic Co-operation and Development (Organisation for Economic Co-operation and Development [OECD], 2002) definesneuromyths as "misconception[s] generated by a misunderstanding, a misreading, or a misquoting of facts scientifically established (by brain research) to make a case for use of brain research in education and other contexts" (p. 111). Neuromyths have been identified with respect to various topics, such as indicators for specific learning difficulties like dyslexia (Macdonald et al., 2017) or the influence of nutrition (Dekker et al., 2012) and music (Düvel et al., 2017) on the brain. However, the lack of standardized methods for classifying misconceptions about learning and the brain as neuromyths and/or investigating new neuromyths remains an issue. Empirical studies often publish lists declaring various misconceptions to be neuromyths without defining the neuromyth construct more precisely, pointing out the logical fallacies at the root of the relevant misconceptions or juxtaposing them with their scientific refutations (e.g., Herculano-Houzel, 2002; Dekker et al., 2012). As a result, interested parties in the education system are unable to adequately inform themselves about neuromyths. Grospietsch (2019) made a first attempt to more precisely define scientific myths as a general construct. According to her, scientific myths exist on various topics in the natural sciences, including the iron content of spinach, an alleged link between vaccines and autism, or the effectiveness of the 'blood type' diet (Schaal, 2018). The widespread misconceptions that exist about the nature of science (McComas, 1998) can also be classified as scientific myths. Scientific myths can be created either by the general public or by scientists themselves (Bodenmann, 2009) when aspects of scientific argumentation and the nature of science are neglected. They can spread rapidly, can be highly resistant to change, and can be facilitated or strengthened by the following backfire effects (Grospietsch and Mayer, 2021a):

1. The mere mention of a memorable scientific myth can lead to its long-term retention (familiarity backfire effect).

2. Too many scientific arguments against a scientific myth can make the more simply formulated myth seem even more attractive (overkill backfire effect).

3. When people are strongly convinced of a scientific myth, their processing of counterarguments may be skewed, leading whether consciously or unconsciously - to a further strengthening of the scientific myth (worldview backfire effect).

Based on this theoretical foundation regarding the scientific myths construct and a content analysis of neuromyths on the subtopic of learning and memory, Grospietsch (2019) came to define neuromyths as misconceptions based on a kernel of 'truth', meaning that they take a scientific term or research finding (= neurofact) as a starting point for their argumentation,

${ }^{2}$ Truth' is placed in quotes here because this term should not be understood to mean that scientific findings can ever be proven beyond all doubt (cf. Nature of Science). 
which morphs into a no-longer-scientifically-accurate implication for teaching and learning (= neuromyth) through a series of erroneous conclusions and logical fallacies. The starting points for these fallacious lines of argumentation are findings from neuroscience or cognitive psychology. Although many theoretical descriptions of individual neuromyths exist that delineate certain individual arguments or counterarguments, only ten neuromyths have been systematically described with respect to their kernel of truth, individual erroneous conclusions and appropriate counterarguments (Grospietsch and Mayer, 2018; 2019; 2021a; 2021b; Grospietsch 2019). Only such systematic descriptions make it possible for recipients to grasp the fallacious lines of argumentation that underlie neuromyths. That is why the present article covers these ten neuromyths on the subtopic of learning and memory in detail. They are presented based on the systematic descriptions by Grospietsch and Mayer (2018, 2019, 2021a, b and Grospietsch 2019), which in turn follow the methodology of scientific clarification (Kattmann et al., 1997).

There is an abundance of theoretical descriptions of the neuromyth on the existence of learning styles (Looß, 2001; Geake, 2008; Pashler et al., 2008; Alferink and FarmerDougan, 2010; Lilienfeld et al., 2010; Adey and Dillon, 2012; Lethaby and Harries, 2016; Tokuhama-Espinosa, 2018; Meinhardt, 2019; Newton and Salvi, 2020; Papadatou-Pastou et al., 2020). According to Grospietsch and Mayer (2021b), the kernel of truth behind this neuromyth is that people differ in the mode in which they prefer to receive information (visually or verbally; e.g., Höffler et al., 2017). The first erroneous conclusion that can be drawn from this kernel of truth is that there are auditory, visual, haptic and intellectual learning styles, as Vester (1975) suggested in the German context. ${ }^{3}$ The next erroneous conclusion drawn is that people learn better when they obtain information in accordance with their preferred learning style. Finally, the third erroneous yet widely disseminated conclusion is that teachers must diagnose their students' learning styles and take them into account in instruction. In contrast, the scientifically accurate perspective is as follows: Vester's model of learning styles is not even logically consistent, because it compares three sensory channels to an 'intellectual' learning style (Looß, 2001). Tests of learning styles are unreliable from a measurement perspective and are unable to accurately categorize heterogenous groups of learners (Coffield et al., 2004; Pashler et al., 2008). Four learning styles cannot even come close to describing learning processes, which are as individual as a fingerprint. Moreover, there is no empirical evidence confirming the effectiveness of considering students' learning styles in instruction (Willingham et al., 2015). Regardless of the mode in which it is presented, information must be meaningfully processed, repeated and elaborated. A balanced repertoire of learning strategies is important here (Newton, 2015; Lethaby and Harries, 2016). If a person feels that they learn best by writing the content down in their own words, this is

${ }^{3}$ For an international overview of prominent learning styles models, see Coffield et al. (2004). not because they then see what they have written down, but rather because writing something down in one's own words serves as an elaboration strategy (Grospietsch and Mayer, 2021b).

There are numerous theoretical descriptions and speculations about the origin of the neuromyth that we only use $10 \%$ of our brains (Beyerstein, 2002; Geake, 2008; Lilienfeld et al., 2010; Adey and Dillon, 2012; Jarrett, 2014; Tokuhama-Espinosa, 2018). According to Grospietsch and Mayer (2019), the kernel of truth underlying this neuromyth is that contemporary imaging techniques can show which specific regions of the brain are involved in certain mental or physical activities. For example, many fMRI images exist in which only a portion of the brain is highlighted in color. The erroneous conclusion drawn from this kernel of truth is that only these highlighted regions are active and the gray-shaded regions are completely inactive. Other assumptions include the existence of a 'silent cortex' with no function at all and that only $10 \%$ of our brain consists of neurons, with the rest consisting of functionless glia cells. This leads to the erroneous conclusion that learners' brain capacity can and must be increased. In contrast, from a scientifically accurate perspective, fMRIs and other such images are based on differential imaging techniques, in which only regions that exceed a certain baseline level of activity are highlighted in color (Darvas et al., 2004). Even the grey-shaded regions are in a kind of 'standby mode' involving anticipatory activity (Whittingstall and Logothetis, 2009). Beck (2016) compares this to a football pitch: Just because one player has the ball, the other ten players on the team are not inactive. Likewise, allegedly 'silent' regions of the cerebral cortex belong to the association cortex and have important functions for higherlevel psychological, psychosocial and mental abilities (Bear et al., 2016), and the ratio of neurons to glia cells is not 1:10 but actually about 1:1 (von Bartheld et al., 2016). Moreover, glia cells are not functionless. They take on important functions to support neurons and are also involved in memory formation (Hilgetag and Barbas, 2009).

Several theoretical descriptions of the neuromyth regarding learning differences due to hemispheric use also exist (Organisation for Economic Co-operation and Development [OECD], 2002; Becker, 2006; Geake, 2008; Alferink and Farmer-Dougan, 2010; Lilienfeld et al., 2010; Lindell and Kidd, 2011; Adey and Dillon, 2012; Jarrett, 2014; TokuhamaEspinosa, 2018). According to Grospietsch (2019), the kernel of truth underlying this neuromyth is that one brain hemisphere is more strongly involved in certain cognitive processes than the other (hemispheric dominance) (e.g., Ocklenburg et al., 2014; Bear et al., 2016). Based on this kernel of truth, it is erroneously concluded that the two brain hemispheres have different strengths and weaknesses. It is assumed that every person has a dominant hemisphere that they rely upon more strongly than the other, and that learners' (cognitive) characteristics are rooted in this 'hemispheric dominance' misinterpreted as the strength of the two hemispheres. For example, analogously to the neuromyth that logic is located in the left hemisphere, creativity in the right (see below), it is allegedly the case that 'left brain dominant' learners are more talented in mathematics, while 'right brain dominant' learners 
are better able to complete creative tasks. Ultimately, the erroneous conclusion is drawn that learners cannot complete tasks that misalign with their hemispheric dominance or can do so only with great difficulty; thus, teachers need to take into account whether learners are left-brained or right-brained in their instruction. From a scientifically accurate perspective, however, it is learners themselves rather than brain hemispheres that possess different strengths and weaknesses rooted in their intelligence, use of learning strategies, interest, motivation, attention, etc. (Gruber, 2018). Hemispheric dominance merely means that one of the two hemispheres is more strongly involved in a specific cognitive process than the other. As will be explained in the next paragraph on the neuromyth that logic is located in the left hemisphere, creativity in the right, functions are lateralized only to a certain extent. Generally speaking, information is stored throughout the entire architecture of a given neural network and thus in memory traces (engrams) throughout the brain. As long as the corpus collosum, the band of nerves linking the two hemispheres, remains intact, a constant exchange of information between the two hemispheres takes place, regardless of the type of activity being conducted (Bear et al., 2016).

The neuromyth that logic is located in the left hemisphere, creativity in the right (e.g., Hines, 1991) exhibits some thematic overlap with the neuromyth concerning learning differences due to hemispheric use. The two neuromyths are frequently described in relation to one another (Organisation for Economic Co-operation and Development [OECD], 2002; Alferink and Farmer-Dougan, 2010; Tokuhama-Espinosa, 2018; Meinhardt, 2019). According to Grospietsch and Mayer (2019), the kernel of truth underlying this neuromyth is that the cerebrum contains two hemispheres that are not completely identical from an anatomical or functional perspective (hemispheric asymmetry; e.g., Jäncke, 2013; Ocklenburg et al., 2014). The neuromyth that logic is located in the left hemisphere, creativity in the right is based on this kernel of truth, yet taken to the erroneous conclusion that each hemisphere works autonomously and has a different function: The left hemisphere is responsible for intellectual, rational, verbal and analytical thinking, while the right hemisphere is responsible for creative, intuitive and non-verbal thought processes. It is further erroneously concluded that schools and society at large place too much emphasis on the left hemisphere, unduly straining this side of the brain. This leads to the recommendation that both hemispheres be addressed equally and interactions between them be facilitated. From a scientifically accurate perspective, however, the two hemispheres are linked to one another via the corpus collosum, as mentioned above (Bloom and Hynd, 2005). They work together on all processing tasks (Singh and O'Boyle, 2004), as can be illustrated with the example of language: The left hemisphere is predominant in many but not all verbal processes. A few components of language are processed in the right hemisphere, including intonation and reading between the lines (Lai et al., 2015). Thus, the process is not completely lateralized (Nielsen et al., 2013).

A further neuromyth related to the relationship between the brain hemispheres concerns the effectiveness of Brain Gym
(Becker, 2006; Hyatt, 2007; Stephenson, 2009; Howard-Jones, 2010; Adey and Dillon, 2012; Tokuhama-Espinosa, 2018). According to Grospietsch and Mayer (2021a), the kernel of truth underlying this neuromyth is that a crossed neural pathway links the left hemisphere of the brain to the right side of the body and vice versa (e.g., De Lussanet and Osse, 2012; Kinsbourne, 2013). Based on this kernel of truth, it is erroneously concluded that motor problems during cross-body coordination exercises result from a lack of coordination between the two hemispheres. Learning difficulties are also said to result from a lack of cooperation between the two hemispheres. It is further erroneously concluded that cooperation between the two hemispheres can be improved by increasing the number of synaptic connections between them and that cross-body coordination exercises can improve one's mental abilities. Ultimately, it is claimed that 'Brain Gym' programs available for sale can prevent learning difficulties, improve students' learning or creativity, and even raise their intelligence. From a scientifically accurate perspective, however, the two brain hemispheres are constantly exchanging information in coordination with one another as long as the corpus collosum, the band of nerves linking the two hemispheres, remains intact (Blais et al., 2018). Learning difficulties are instead attributable to differences in working memory capacity or processing speed (Willcutt et al., 2013). They can also be caused by a lack of attention, unfavorable motivational conditions, or deficits in the use of learning strategies (Creß and Friedrich, 2000; Grube and Ricken, 2016). We cannot consciously influence where synapses arise, and their formation is not a unique occurrence. New synaptic links form during each and every cognitive process (Zheng et al., 2013). While coordination exercises can improve students' physical fitness levels and motor skills, they do not improve their cognitive performance (Cancela et al., 2015). Any subjectively or objectively perceived cognitive improvements result instead from the break from learning/improved circulation that accompanies such exercises (Budde et al., 2008).

The neuromyths that the best learning occurs before age three and that there are critical time periods for learning are likewise tightly interwoven with one another and often described together (Bruer, 2000; Organisation for Economic Co-operation and Development [OECD], 2002; Organisation for Economic Cooperation and Development [OECD], 2005; Alferink and Farmer-Dougan, 2010; Howard-Jones 2010; Adey and Dillon, 2012). According to Grospietsch and Mayer (2020), the kernel of truth underlying the notion that the best learning occurs before age three (e.g., Bruer, 2000; Tokuhama-Espinosa, 2018) is that the number of neural connections in the brain increases massively during the first years of life (e.g., Bianchi et al., 2013; Carter, 2014). Based on this kernel of truth, it is erroneously concluded that more synaptic connections in the brain is equivalent to a high level of intelligence. It is further assumed that adults' brains function worse than children's brains and that all structural changes as we age are negative. The erroneously conclusion drawn from this is that brain development can and must be influenced during early childhood (Organisation for Economic Co-operation and Development [OECD], 2002). From a scientifically accurate perspective, however, particularly intelligent people are actually 
characterized by a reduced number of neural connections (Genç et al., 2018). Likewise, structural differences between children's and adults' brains have nothing to do with their quality of learning (Geerligs et al., 2015). Young people can process new information more quickly and efficiently in smaller, more differentiated networks, while older people process new information in broader, better linked neural networks (Organisation for Economic Co-operation and Development [OECD], 2002). Moreover, structural changes during adulthood are not necessarily negative: For example, prefrontal cortex development and myelination (in which the axons of nerve fibers are encased in myelin) continue until age 30, meaning that only adults are fully capable of well-thought-out reactions and moral decision-making (Carter, 2014) and able to more quickly and efficiently transfer information across far-flung regions of the brain (Spear, 2013). Furthermore, we cannot deliberately influence either the overproduction of synapses during early childhood or their subsequent pruning in favor of strengthening other types of neural connections that increase the neural network's efficiency (Casey et al., 2000; Bianchi et al., 2013).

The kernel of truth underlying the neuromyth concerning critical time periods for learning (Howard-Jones, 2010; Adey and Dillon, 2012; Tokuhama-Espinosa, 2018), according to Grospietsch and Mayer (2020), is that certain things can be learned more easily during particular sensitive phases during childhood (Thomas and Johnson, 2008; Carter, 2014). Based on this kernel of truth, it is erroneously concluded that children are capable of unlimited learning during their first years of life. It is also assumed that the construction of neural connections (synapses) can be facilitated by exposing children to the 'right' stimuli (e.g., reading aloud). Thus, it is claimed that exposure to certain 'special' stimuli in early childhood (e.g., classical music) leads to higher cognitive performance in adulthood (e.g., mathematical thinking). Children must therefore be presented with as many 'good' stimuli as possible during this time window, which then closes irrevocably, in order to avoid lifelong learning impairments that cannot be corrected later through education. From a scientifically accurate perspective, however, while it is true that children learn many new things in their first years of life (crawling, standing, walking, speaking, etc.), they do not possess 'unlimited learning capacity' (Bruer, 1997; Bruer, 2000). Learning is not determined by stimuli themselves, but by how they are processed. In general, when and how neural connections form cannot be deliberately controlled, and in fact, the neural network changes with every stimulus that is processed (Bear et al., 2016). No neuroscientific studies have ever demonstrated that long-term exposure to certain stimuli such as music has a positive influence on the brain (Perani et al., 2010) or that certain abilities can only be learned during a critical time window that opens at a certain time and later closes permanently (Thomas and Johnson, 2008; Howard-Jones, 2014). Negative consequences (in the sense of irreversible damage) are only a risk when complete deprivation of all stimuli takes place. For example, the central visual pathway cannot develop in the absence of visual stimuli (Bear et al., 2016). However, such cases are a very rare exception (Bruer, 1997; Bruer, 2000).

The neuromyth on learning while you sleep is theoretically described much more rarely compared to the aforementioned neuromyths (Centre for Educational Research and Innovation [CERI], and Organisation for Economic Co-operation and Development [OECD], 2007; Lilienfeld et al., 2010; TokuhamaEspinosa, 2018). Based on the kernel of truth (Grospietsch and Mayer, 2019) that nighttime restructuring (consolidation) processes in the brain can lead to new insights, one might erroneously conclude that people can learn completely new content while they sleep; they can use the time they spend sleeping for learning by exposing themselves to acoustic stimuli. This leads to the recommendation that learners should play audio files (e.g., vocabulary words in a new language) while they sleep. From a scientifically accurate perspective, however, information is encoded when a person is awake, and consolidated while they sleep. Both processes are necessary to store knowledge in long-term memory - in other words, to learn (Gais and Born, 2004). It is not possible to learn new content while one sleeps (Stickgold, 2012). Encoding new information during sleep would disturb the consolidation process for information encoded earlier (Gais and Born, 2004). During sleep, the brain is relatively strongly sealed off from the outside world (Muzet, 2007), although it can react to sensory inputs like smells by modifying the intensity of breathing (Stickgold, 2012), making conditioning possible (Arzi et al., 2012).

A further neuromyth that tends to be described in research on school students' (mis)conceptions is the existence of specific storage locations (hard drive) in the brain (cf. Schletter and Bayrhuber, 1998). According to Grospietsch (2019), the kernel of truth underlying this neuromyth is that the cerebrum contains various cortical regions with a functional division of tasks. From this, it is erroneously concluded that a kind of map can be drawn showing what is stored or processed where in the brain and what functions this entails. Thus, it is assumed that each region of the cerebral cortex functions as an autonomous center for certain tasks, with fixed regions responsible for topics such as mathematics. The conclusion drawn from this is that a single center for mathematics, for instance, exists in the brain that can be addressed in a targeted way. From a scientifically accurate perspective, however, as was the case for the neuromyth that we only use $10 \%$ of our brains, the corresponding research findings are based on differential imaging and depict an augmented but not complete division of tasks. Different regions of the brain are not isolated 'islands'; they communicate, influence and work together with one another (Anderson, 2010). Information is always processed and stored in parallel in multiple locations of the brain (LeDoux, 2007).

A neuromyth that has to date largely been addressed in the context of cognitive psychology and 'desirable difficulties' (e.g., Bjork and Bjork, 2011; Lipowsky et al., 2015) is the notion that blocked learning is better than interleaved (Grospietsch and Mayer, 2019). According to Grospietsch (2019), the kernel of truth underlying this neuromyth is that instructional designs in which the learning content is systematically structured facilitate positive learning effects among students (e.g., Hattie, 2009). From this, it is erroneously concluded that students become overwhelmed when instructional topics are not taught one after another in a structured, sequential way. A related assumption is that students' knowledge acquisition is more sustainable when the learning process is simplified, and quick and easy success during 
learning improves students' long-term retention of the learning content. Thus, it is recommended that teachers follow the structure of school textbooks and teach topics one after another chronologically. From a scientifically accurate perspective, however, students who engage in interleaved learning (mixed, juxtaposed learning of different topics) have better scores on long-term performance tests (after several weeks or months have passed) and develop fewer misconceptions than students who sequentially learn content on one topic after another (e.g., Rohrer and Taylor, 2007; Ziegler and Stern, 2014). Research findings on desirable difficulties demonstrate the positive effects on students' knowledge acquisition of deliberately making learning processes more difficult (e.g., Bjork and Bjork, 2011; Dunlosky et al., 2013; Lipowsky et al., 2015) and that interleaved learning is superior to blocked learning in the long term (e.g., Mayfield and Chase, 2002). Cognitively demanding activities result in slow, not immediately visible learning successes, yet improve long-term retention of what has been learned (e.g., Carvalho and Goldstone, 2014; Bjork and Kroll, 2015).

Apart from the studies applied by Grospietsch and Mayer (2018, 2019, 2021a, b and Grospietsch 2019) to provide a scientific clarification (Kattmann et al., 1997) of the aforementioned neuromyths, few further theoretical descriptions of other neuromyths exist (e.g., in Jarrett, 2014; Beck, 2016; Tokuhama-Espinosa, 2018). Beyond the subtopic of learning and the brain, the best described neuromyths concern multiple intelligences theory (Geake, 2008; Howard-Jones, 2010), the consumption of sugary snacks and drinks (Howard-Jones, 2010) and water (Dündar and Gündüz, 2016). There is also extensive work on psychological myths (e.g., Lilienfeld et al., 2010), to which the aforementioned neuromyths we only use $10 \%$ of our brains, learning differences due to hemispheric use (McCarthy and Frantz, 2016) and existence of learning styles (Menz et al., 2020) can also be considered to belong. ${ }^{4}$ For other cases, such as the myth that our genetically determined number of cells determines learning success (examined in a study by Bellert and Graham, 2013), the theoretical state of research must be considered highly deficient.

\section{EMPIRICAL STATE OF RESEARCH ON NEUROMYTHS}

Numerous empirical studies ${ }^{5}$ reveal that even though pre-service and in-service teachers as well as university instructors exhibit great interest in neuroscience, they are unable to differentiate neuromyths from "neurofacts"6 (Grospietsch and Mayer, 2020). Studies demonstrating endorsement of neuromyths among inservice teachers have been conducted in England (Dekker et al., 2012; Simmonds, 2014; Horvath et al., 2018), the Netherlands

\footnotetext{
${ }^{4}$ This review will not further report on studies concerning psychological myths. ${ }^{5}$ This review includes all studies on the keyword "neuromyths" found via ERIC, PubMed and ResearchGate up to May 2021, that underwent peer review and/or were reviewed in such studies.

${ }^{6}$ This term is used in many studies of neuromyths. However, it is problematic from a nature of science perspective, since the natural sciences cannot yield 'proven' facts, but only ever preliminary results.
}

(Dekker et al., 2012), Switzerland (Tardif et al., 2015), Italy (Tovazzi et al., 2020), Spain (Ferrero et al., 2016), Portugal (Rato et al., 2013), Greece (Deligiannidi and Howard-Jones, 2015), Turkey (Karakus et al., 2015), Morocco (Janati Idrissi et al., 2020), China (Pei et al., 2015), Australia (Bellert and Graham, 2013; Horvath et al., 2018), Canada (Lethaby and Harries, 2016; Blanchette Sarrasin et al., 2019), United States (Lethaby and Harries, 2016; Macdonald et al., 2017; Horvath et al., 2018; van Dijk and Lane, 2018) and Latin America (Herculano-Houzel, 2002; Bartoszeck and Bartoszeck, 2012; Gleichgerrcht et al., 2015; Hermida et al., 2016; VarasGenestier and Ferreira, 2017; Bissessar and Youssef, 2021). Studies demonstrating endorsement of neuromyths among pre-service teachers have been conducted in England (Howard-Jones et al., 2009; McMahon et al., 2019), Germany (Düvel et al., 2017; Grospietsch and Mayer, 2018; 2019), Switzerland (Tardif et al., 2015), Austria (Krammer et al., 2019; 2020), Slovenia (Škraban et al., 2018); Spain (Fuentes and Risso, 2015), Greece (Papadatou-Pastou et al., 2017), Turkey (Dündar and Gündüz, 2016; Canbulat and Kiriktas, 2017), South Korea (Im et al., 2018), Australia (Kim and Sankey, 2017), United States (Ruhaak and Cook, 2018; van Dijk and Lane, 2018) and Latin America (Herculano-Houzel, 2002; Falquez Torres and Ocampo Alvarado, 2018). The majority of such studies focus on pre-service and in-service teachers across all subjects and school types. Their findings consistently show that pre-service and in-service teachers endorse a large number of neuromyths, despite some (country-specific ${ }^{7}$ ) differences in the endorsement of certain individual myths (Grospietsch and Mayer, 2020). The hypothesis that cultural differences between countries influence which neuromyths gain currency where has taken hold in the research discourse (e.g., Pei et al., 2015; Ferrero et al., 2016; Hermida et al., 2016), even though this has not yet been systematically tested.

A few studies on neuromyths investigate specific groups such as post-graduate teacher trainees (Howard-Jones et al., 2009), pre-service special education teachers (Ruhaak and Cook, 2018), school principals (Zhang et al., 2019), or pre-service music (Düvel et al., 2017) and biology teachers (Grospietsch and Mayer, 2018; Grospietsch and Mayer, 2019). Comparisons of different groups are undertaken by Canbulat and Kiriktas (2017), Dündar and Gündüz (2016), Düvel et al. (2017), Gleichgerrcht et al. (2015), Herculano-Houzel (2002), Horvath et al. (2018), Macdonald et al. (2017), Simmonds (2014), Tardif et al. (2015) and van Dijk and Lane (2018). Macdonald et al. (2017) show that members of the general public endorse neuromyths more frequently than educators and persons with high neuroscience exposure. Herculano-Houzel (2002) likewise identifies a significant difference between the general public and neuroscientists. Her study finds differences between high school respondents, college respondents, graduate respondents, psychology students and neuroscientists (listed in order of decreasing endorsement of neuromyths). According to Gleichgerrcht et al. (2015) and van Dijk and Lane (2018), university professors and instructors in the

${ }^{7}$ Howard-Jones (2014) compares seven neuromyths across five countries in four cited studies. 
field of teacher education exhibit slightly lower endorsement of neuromyths compared to (pre-service) teachers. In a study by Canbulat and Kiriktas (2017), in-service teachers endorse neuromyths slightly less frequently than pre-service teachers. These findings contradict those by Tardif et al. (2015), who found stronger endorsement of many neuromyths among in-service teachers. Zhang et al. (2019) and Horvath et al. (2018) demonstrate that even school principals and award-winning teachers endorse neuromyths with a high frequency. With the exception of the aforementioned differences, empirical findings on the prevalence of neuromyths can be considered quite consistent: Neuromyths are not sufficiently disavowed particularly among teachers and university instructors, who are frequently assumed to be professionals in teaching and learning. Endorsement of the neuromyths on the existence of learning styles and the effectiveness of Brain Gym, which have found their way into learning guides and educational programs, is particularly high among these two groups as well as all other studied groups (Grospietsch and Mayer, 2020).

Tardif et al. (2015) demonstrate that (pre-service) teachers come into contact with neuromyths and associated practices during both their academic and practical training. A study by Howard-Jones et al. (2009) confirms that $56-83 \%$ of pre-service teachers encounter educational programs rooted in neuromyths during their first year of practical training in schools, which is associated with a high level of acceptance of these myths. Simmonds (2014) shows that many teachers use or have used unproven techniques such as Brain Gym in their instruction. Lethaby and Harries (2016) and Blanchette Sarrasin et al. (2019) provide evidence that many teachers who endorse neuromyths also employ instructional practices linked to these misconceptions in their classrooms (this is the case more frequently among preschool and elementary school teachers than secondary school teachers). Grospietsch and Mayer (2019) found a small positive association between endorsement of neuromyths and constructivist beliefs about teaching and learning. This association might indicate that highly engaged, innovative teachers are the ones who make a well-intentioned effort to incorporate ostensibly neurodidactic principles into their instruction. Conversely, Ruhaak and Cook (2018) show that teachers with accurate conceptions regarding neuromyths are more likely to employ effective instructional practices rather than ineffective ones based on neuromyths. Horvath et al. (2018) rightly criticize that the association between endorsement of neuromyths and teaching effectiveness has not yet been sufficiently investigated to conclude that endorsement of neuromyths has (negative) consequences for the education system. Nevertheless, their finding that non-awardwinning teachers do not differ from award-winning teachers in their endorsement of neuromyths also does not allow conclusions to be drawn as to whether inaccurate content and/or ineffective learning strategies are being passed on to learners and/or the education system's "money, time and effort" (Dekker et al., 2012, p. 1) are being wasted on the implementation of neuromyths.

Research results on the factors affecting endorsement of neuromyths are diverse. Ferrero et al. (2016) show that reading pedagogical magazines increases endorsement of neuromyths. In contrast, Düvel et al. (2017) find that reading a large number of pedagogical books, magazines and websites reduces endorsement of neuromyths. Similarly, Macdonald et al.
(2017) and Ferrero et al. (2016) find that reading scientific articles reduces endorsement in neuromyths. Conversely, Gleichgerrcht et al.'s (2015) findings suggest that neither popular science nor neuroscientific articles sufficiently reduce beliefs in neuromyths. Papadatou-Pastou et al. (2017) identify general knowledge about the brain as the best "safeguard against believing in neuromyths" (p. 1). This is confirmed by studies by Howard-Jones et al. (2009) and van Dijk and Lane (2018). Nevertheless, in many studies, teachers who endorse scientifically appropriate conceptions about the brain to a high degree are more susceptible to believing in neuromyths (e.g., Dekker et al., 2012; Ferrero et al., 2016). Findings with respect to relevant personal characteristics are similarly diverse. The majority of studies find no associations between endorsement of neuromyths and age, gender, job experience, school subject, school type, school location (urban/rural) or completion of professional development courses (e.g., Dekker et al., 2012; Rato et al., 2013; Karakus et al., 2015; Papadatou-Pastou et al., 2017). Macdonald et al. (2017) show that a lower age, university degree and enrollment in neuroscience courses reduce but do not eliminate endorsement of neuromyths. Canbulat and Kiriktas (2017) and Ruhaak and Cook (2018) come to similar conclusions. Four studies report an association between endorsement of neuromyths and gender. In two of these studies, male teachers are more likely to believe in neuromyths (Canbulat and Kiriktas, 2017; Macdonald et al., 2017), while in the other two studies, their results are better than those for female participants (Dündar and Gündüz, 2016; Ferrero et al., 2016).

While the existing literature on neuromyths calls for integrating more neuroscience into teacher education (e.g., Howard-Jones, 2014), this alone does not seem sufficient to reduce pre-service and in-service teachers' misconceptions on the topic of learning and the brain. Although Dündar and Gündüz (2016) find that preservice science teachers significantly outperform pre-service teachers of other subjects, findings by Macdonald et al. (2017) and Im et al. (2018) indicate that merely enrolling in neuroscience or psychology courses during university teacher education does not sufficiently reduce beliefs in neuromyths. Indeed, Grospietsch and Mayer (2019) find that even pre-service biology teachers, for whom neuroscientific content is part of their studies (e.g., courses in human biology and animal physiology), endorse neuromyths to a great extent. Moreover, in their study, endorsement of neuromyths was largely independent of the pre-service teachers' professional knowledge as well as theory-based and biography-based learning beliefs. Respondents in different stages of their training (first-semester students, advanced students and post-graduate teacher trainees) differed only with respect to their endorsement of scientifically accurate conceptions ${ }^{8}$, not in their endorsement of neuromyths. Given that biology teachers need to not only be able to address the topic of learning and the brain as instructional content but also use it to guide their students' learning processes, the (mis)conceptions found among pre-service biology teachers up to and including the

\footnotetext{
${ }^{8}$ Meant here is what is captured in almost all neuromyths studies with a scale on "neurofacts". An example item is We use our brains $24 h$ a day. For more information, see e.g., Dekker et al. (2012).
} 
post-graduate teacher training phase must be considered deficient. Grospietsch and Mayer (2019) findings further suggest that misconceptions are resistant to traditional teacher education, which means that new teachers enter the practice with misconceptions despite their acquisition of professional knowledge.

Grospietsch and Mayer (2021a) show that university students make not only scientific (neuroscientific and cognitive psychological) arguments in favor of neuromyths but also biographical arguments based on their personal experiences. Moreover, refutation can actually bolster their misconceptions (= worldview backfire effect, see theoretical state of research). Indeed, university students mention many more erroneous conclusions and arguments in favor of neuromyths that previously assumed theoretically. Work by Petitto and Dunbar (2004) demonstrates that university students can stubbornly cling to their original misconceptions in the face of empirical demonstrations and theoretical accounts. Newton and Miah (2017) and Rousseau and Brabant-Beaulieu (2020) confirm this specifically with respect to the neuromyth on the existence of learning styles. According to a study by Kim and Sankey (2017), pre-service teachers may have come into contact with neuromyths even before beginning their studies, during their own time at school. They can be quite convinced of their misconceptions as a result of their practical experiences or consider them to be intuitively correct (cf. Blanchette Sarrasin et al., 2019). These are all potential reasons why there are currently few effective interventions to combat neuromyths (Grospietsch and Mayer, 2018, 2021a; McMahon et al., 2019). Findings by Grospietsch and Mayer (2018) show that even a university course imparting professional knowledge from the fields of cognitive psychology, neuroscience and biology education on the topic of learning and the brain in a deeply interlinked way is not sufficient for students to critically engage with neuromyths. Explicitly addressing, refuting and encouraging students to reflect on their own misconceptions as can be the case when using conceptual change texts (on seven neuromyths, published in Grospietsch and Mayer, 2021b) - is necessary to sustainably reduce them. Instructional strategies and methods that take up students' misconceptions, deliberately provoke a cognitive conflict, and then systematically expand them in the direction of scientifically accurate concepts have been found to be particularly effective at combating neuromyths (Grospietsch and Mayer, 2018; 2021a). Howard-Jones (2014), Grospietsch and Mayer (2020) and Torrijos-Mualas et al. (2021) provide first (systematic) reviews of the state of empirical research on neuromyths.

\section{DISCUSSION AND OUTLOOK}

\section{Controversies, Fundamental Concepts, Issues, and Problems in the Research Field of Neuromyths}

This article has summarized the state of theoretical and empirical research on neuromyths. The first controversial aspect that can be identified is that many research findings on correlations with endorsement of neuromyths contradict one another. According to Krammer et al. (2019), these contradictory findings could be a methodological artifact, as most existing studies applied Dekker's et al., (2012) instrument and uncritically assumed the unidimensionality of all specified neuromyths (an exception is Macdonald et al.'s, 2017). The response format applied (Yes/No/I don't know) has been also criticized from a methodological perspective (Krammer et al., 2019). Grospietsch and Mayer (2019) developed an instrument that asks respondents about neuromyths solely on the subtopic of learning and memory and applies a Likert scale, in accordance with Macdonald et al.'s (2017) recommendations. Tovazzi et al. (2020) recently developed an instrument for a few neuromyths that focuses more on procedural rather than declarative knowledge. Ultimately, however, these contributions have been seldom adopted, and new empirical studies and systematic reviews largely pass on the results and instruments that (continue to) shape the current state of research (e.g., Torrijos-Mualas et al., 2021).

Another aspect that can be considered controversial is that the theoretical state of research on neuromyths (What assumptions do we have about how pre-service and in-service teachers argue in favor of neuromyths?) contradicts Grospietsch's and Mayer's, (2019) empirical results (What fallacious arguments are actually employed?). In this study, pre-service teachers named many more arguments for neuromyths than previously assumed theoretically, and the neuromyth items that dominate the research discourse evoked very different associations for the participants. Grospietsch and Mayer (2019) critically conclude on the basis of their theoretical work on neuromyths that instruments need to more consistently ask questions about neuromyths' kernel of 'truth', individual erroneous conclusions, and the specialized knowledge needed to refute them. This could deliver more detailed starting points for interventions while simultaneously reducing the risk of failing to recognize that certain neuromyths build or rely upon one another and thus including them multiple times (cf. Krammer et al., 2019). Furthermore, Grospietsch and Mayer (2019) and Torrijos-Muelas et al. (2021) call for more (qualitative) studies of neuromyths in order to learn more about their genesis and causes and capture their 'actual' and not merely theoretically assumed chains of erroneous conclusions (see Theoretical State of Research) in greater detail (e.g., Newton and Salvi, 2020; Papadatou-Pastou et al., 2020).

\section{Current Research Gaps}

Alongside the aforementioned methodological critique of the research field concerning neuromyths and the areas for further research presented here, our presentation of the theoretical and empirical state of research allows for the identification of three central research gaps that should shape the research discourse in the coming decade. First, studies should be conducted on whether and to what extent the endorsement of neuromyths really deprives teachers and students of opportunities to spend the educational system's money, time and effort on more effective theories and methods (e.g., teaching learning strategies or cognitive activation). Horvath et al. (2018) criticize that there is currently only speculation on this point and perhaps an unjust 'overdramatization'. Second, this review article demonstrates that neuromyths remain a subject of attention almost two decades after they were first defined. However, even though the problem 
has been known for so long, there has been relatively little work on developing and evaluating intervention approaches (e.g., Grospietsch and Mayer, 2018, 2021a; McMahon et al., 2019). The majority of neuromyth studies are fundamentally content to replicate 'old' findings on neuromyths, even though many other studies - sometimes from the same country - show that developing university courses and professional development opportunities for in-service teachers that are able to sustainably reduce endorsement of neuromyths represents a much more important goal (e.g., Craig et al., 2021). The third research gap that can be identified based on this review is that there is no standard scientific methodology or guidelines for determining new neuromyths, as was also corroborated by Torrijos-Muelas et al. (2021). Although recent work by Grospietsch and Mayer (2018; 2019; 2021a; 2021b) and Grospietsch (2019) has contributed to a more detailed classification of scientific myths and neuromyths, many open questions remain, such as: What level of endorsement does a neuromyth need to enjoy in order to be categorized as such? Put bluntly: Are misconceptions on the topic of learning and the brain held by no one or by only a single person really neuromyths? The example a genetically determined number of cells determines learning success (examined in a study by Bellert and Graham, 2013) demonstrates that studies have examined neuromyths for which theoretical descriptions and justifications for their classification as part of a neuromyth construct are lacking. The problem we wish to point out is this: Who is actually ensuring that we are not simply including alleged neuromyths in our research without critical examination and with what methods? Based on this review, we call for classifying neuromyths as scientific myths, meaning a specific kind of misconception (Grospietsch and Mayer, 2021a), in a theoretically-driven way, by deriving clearly defined criteria (for example, see the definition by Grospietsch, 2019). Otherwise, one might oneself unwittingly generate or spread a neuromyth.

\section{Potential Developments in the Field}

This review has made clear that there is a need for future researchers to further clarify neuromyths theoretically und empirically. A phenomenon that can be observed at the meta-level is that little work educating people in practice has been conducted despite the existence of numerous theoretical descriptions and studies on neuromyths. Positive examples of providing information about neuromyths include Web-based approaches (e.g., Organisation for Economic Co-operation and Development [OECD], 2015; Rousseau, 2020) and popular science books (e.g., Lilienfeld et al., 2010; Jarrett, 2014; Beck, 2016; Tokuhama-Espinosa, 2018). However, these learning offerings do not apply recent research findings demonstrating the strong, long-term effectiveness of constructivist refutational intervention approaches (e.g., Grospietsch and Mayer, 2018; 2021b). Since (pre-service) teachers primarily rely upon TV, the Internet and popular science magazines to read up on neurodidactics (Rato et al., 2013; Ferrero et al., 2016), there is a need not only for easily accessible, effective educational material clarifying neuromyths, but also for scientifically rooted alternatives to bring research results from the young, vibrant disciplines of educational neuroscience, neuroeducation and Mind, Brain, and Education Science (MBE) into the classroom rather than neuromyths. Grospietsch (2021) translates Grospietsch's, (2019) initial work on a more comprehensive conceptualization of neurodidactics into the language of teachers. This conceptualization is based on knowledge from three disciplines: neuroscience, education and cognitive psychology. The corresponding instructional models demonstrate that psychological models (e.g., multi-storage model of memory, learning strategies theory, the process model of memory formation) can serve as starting points for neuroscientific explanations and foundations for educational conclusions. In a more narrow sense, they function as a bridge between the three disciplines. Grospietsch and Mayer (2020) report based on their research experience that the quality of learning offerings on neuromyths can also be improved through collaboration among the three disciplines.

Taking a meta-perspective view of the theoretical state of research, continued critical attention needs to be paid to the increasing trend of distinguishing between neuromyths and psychological myths (e.g., McCarthy and Frantz, 2016; Menz et al., 2020). This approach is certainly justified on a theoretical level, since some myths can be better refuted with neuroscientific arguments and others with psychological arguments. However, at least for the subtopic of learning and memory, research results by Grospietsch and Mayer (2021a) demonstrate that pre-service teachers apply knowledge from both domains to make fallacious arguments regarding the seven investigated neuromyths. Thus, at this level, the distinction between neuromyths and psychological myths is unsustainable and also not useful for the development of intervention approaches. At a time in which disciplines such as educational neuroscience, neuroeducation and Mind, Brain, and Education Science (MBE) are paving the way for a growing number of interdisciplinary research projects and results, distinguishing between neuromyths and psychological myths is conceptually questionable. Added to this is the fact the relations among studies are not adequately referenced in the research discourse, even though sometimes the same myths are being investigated. Studies on psychological myths (e.g., Menz et al., 2021a; Menz et al., 2021b), in particular, more strongly see scientific myths as a specific kind of misconceptions and deliver valuable insights on interventional approaches that could advance research on neuromyths. Our pragmatic recommendation would be to begin speaking of neuromyths on psychological subtopics or similar, analogously to neuromyths on the subtopic of learning and memory, in order to productively bring together not only different disciplines, but also two diverging lines of research, in the future.

\section{AUTHOR CONTRIBUTIONS}

FG drafted the manuscript. IL provided critical revisions. Both authors approved the final version of the manuscript for submission.

\section{FUNDING}

One of the projects upon which this paper is based is part of the Qualitätsoffensive Lehrerbildung, a joint initiative of the Federal 
Government and the Federal States aiming to improve the quality of teacher training. The programme is funded by the Federal Ministry of Education and Research under the funding code 01JA1505 and 01JA1805. This project was also supported by the LOEWE Excellence Programme Desirable Difficulties in Learning from the Hessian Ministry for Science and the Arts. Another project upon which this paper is based was funded by Germany's Stifterverband.

\section{REFERENCES}

Adey, P., and Dillon, J. (2012). Bad Education: Debunking Myths in Education. Maidenhead: Open Univ. Press.

Alferink, L. A., and Farmer-Dougan, V. (2010). Brain-(Not) Based Education: Dangers of Misunderstanding and Misapplication of Neuroscience Research. Exceptionality 18 (1), 42-52. doi:10.1080/09362830903462573

Anderson, J. R. (2010). Cognitive Psychology and its Implications. 7th edn. New York: Worth Publ. doi:10.21236/ada561318

Arzi, A., Shedlesky, L., Ben-Shaul, M., Nasser, K., Oksenberg, A., Hairston, I. S., et al. (2012). Humans Can Learn New Information during Sleep. Nat. Neurosci. 15 (10), 1460-1465. doi:10.1038/nn.3193

Bartoszeck, A. B., and Bartoszeck, F. K. (2012). How In-Service Teachers Perceive Neuroscience as Connected to Education: An Exploratory Study. Eur. J Ed Res 1 (4), 301-319. doi:10.12973/eu-jer.1.4.301

Bear, M. F., Connors, B. W., and Paradiso, M. A. (2016). Neuroscience: Exploring the Brain. Philadelphia: Wolters Kluwer.

Beck, H. (2016). Hirnrissig: Die 20,5 größten Neuromythen - und wie unser Gehirn wirklich tickt. 2nd edn. München: Wilhelm Goldmann Verlag.

Becker, N. (2006). Die neurowissenschaftliche Herausforderung der Pädagogik. Bad Heilbrunn: Klinkhardt.

Bellert, A., and Graham, L. (2013). Neuromyths and Neurofacts: Information from Cognitive Neuroscience for Classroom and Learning Support Teachers. Spec. Edu. Perspect. 22 (2), 7-20.

Beyerstein, B. L. (2002). "Whence Cometh the Myth that We Only Use $10 \%$ of Our Brains?," in Mind Myths. Exploring Popular Assumptions about the Mind and Brain. Editor S. Della Sala (Chichester: John Wiley \& Sons), 3-24.

Bianchi, S., Stimpson, C. D., Duka, T., Larsen, M. D., Janssen, W. G. M., Collins, Z., et al. (2013). Synaptogenesis and Development of Pyramidal Neuron Dendritic Morphology in the Chimpanzee Neocortex Resembles Humans. Proc. Natl. Acad. Sci. 110 (2), 10395-10401. doi:10.1073/pnas.1301224110

Bissessar, S., and Youssef, F. F. (2021). A Cross-Sectional Study of Neuromyths Among Teachers in a Caribbean Nation. Trends Neurosci. Edu. 23, 100155. doi:10.1016/j.tine.2021.100155

Bjork, E. L., and Bjork, R. A. (2011). "Making Things Hard on Yourself, but in a Good Way: Creating Desirable Difficulties to Enhance Learning," in Psychology and the Real World: Essays Illustrating Fundamental Contributions to Society. Editors M. A. Gernsbacher, R. W. Pew, L. M. Hough, and J. R. Pomerantz (New York: Worth Publishers), 56-64.

Bjork, R. A., and Kroll, J. F. (2015). Desirable Difficulties in Vocabulary Learning. Am. J. Psychol. 128 (2), 241. doi:10.5406/amerjpsyc.128.2.0241

Blais, M., Amarantini, D., Albaret, J.-M., Chaix, Y., and Tallet, J. (2018). Atypical Inter-hemispheric Communication Correlates with Altered Motor Inhibition during Learning of a New Bimanual Coordination Pattern in Developmental Coordination Disorder. Dev. Sci. 21 (3), e12563. doi:10.1111/desc.12563

Blanchette Sarrasin, J., Riopel, M., and Masson, S. (2019). Neuromyths and Their Origin Among Teachers in Quebec. Mind, Brain Edu. 13 (2), 100-109. doi: $10.1111 /$ mbe. 12193

Bloom, J. S., and Hynd, G. W. (2005). The Role of the Corpus Callosum in Interhemispheric Transfer of Information: Excitation or Inhibition? Neuropsychol. Rev. 15 (2), 59-71. doi:10.1007/s11065-005-6252-y

Bodenmann, S. (2009). "Newtons Apfel and Co. Zur Kategorisierung des Mythos in den Naturwissenschaften," in Mythos - Helden - Symbole. Legimitation, Selbst- und Fremdwahrnehmung in der Geschichte der Naturwissenschaften, der Medizin und Technik. Editor S. Splinter (München: Martin Meidenbauer), 1-46.

\section{ACKNOWLEDGMENTS}

In addition to the funding sources mentioned above, FG would like to thank her dissertation supervisor Prof. Jürgen Mayer, who contributed not only to the success of her empirical studies, but also to improving the content of her neurodidactic concept. Both authors would like to thank all assistants and students who have supported their research through dedication and feedback.

Bruer, J. T. (1997). Education and the Brain: A Bridge Too Far. Educ. Res. 26 (8), 4-16. doi:10.3102/0013189x026008004

Bruer, J. T. (2000). Der Mythos der ersten drei Jahre: warum wir lebenslang lernen. Weinheim: Baltz.

Budde, H., Voelcker-Rehage, C., Pietraßyk-Kendziorra, S., Ribeiro, P., and Tidow, G. (2008). Acute Coordinative Exercise Improves Attentional Performance in Adolescents. Neurosci. Lett. 441 (2), 219-223. doi:10.1016/j.neulet.2008.06.024

Canbulat, T., and Kiriktas, H. (2017). Assessment of Educational Neuromyths Among Teachers and Teacher Candidates. Jel 6 (2), 326-333. doi:10.5539/ jel.v6n2p326

Cancela, J. M., Vila Suárez, M. H., Vasconcelos, J., Lima, A., and Ayán, C. (2015). Efficacy of Brain Gym Training on the Cognitive Performance and Fitness Level of Active Older Adults: A Preliminary Study. J. Aging Phys. Activity 23 (4), 653-658. doi:10.1123/japa.2014-0044

Carter, R. (2014). Das Gehirn: Anatomie, Sinneswahrnehmung, Gedächtnis, Bewusstsein, Störungen. München: Dorling Kindersley.

Carvalho, P. F., and Goldstone, R. L. (2014). Effects of Interleaved and Blocked Study on Delayed Test of Category Learning Generalization. Front. Psychol. 5, 936. doi:10.3389/fpsyg.2014.00936

Casey, B. J., Giedd, J. N., and Thomas, K. M. (2000). Structural and Functional Brain Development and its Relation to Cognitive Development. Biol. Psychol. 54, 241-257. doi:10.1016/s0301-0511(00)00058-2

Centre for Educational Research and Innovation [CERI], and Organisation for Economic Co-operation and Development [OECD] (2007). Understanding the Brain: The Birth of a Learning Science. Paris: OECD.

Coffield, F., Moseley, D., Hall, E., and Ecclestone, K. (2004). Learning Styles and Pedagogy in Post-16 Learning: A Systematic and Critical Review. London: Learning and Skills Research Centre.

Craig, H. L., Wilcox, G., Makarenko, E. M., and MacMaster, F. P. (2021). Continued Educational Neuromyth Belief in Pre- and In-Service Teachers: A Call for De-implementation Action for School Psychologists. Can. J. Sch. Psychol. 36 (2), 127-141. doi:10.1177/0829573520979605

Creß, U., and Friedrich, H. F. (2000). Selbst gesteuertes Lernen Erwachsener. Eine Lernertypologie auf der Basis von Lernstrategien, Lernmotivation und Selbstkonzept. Z. für Pädagogische Psychol. 14, 194-205. doi:10.1024//10100652.14.4.194

Darvas, F., Pantazis, D., Kucukaltun-Yildirim, E., and Leahy, R. M. (2004). Mapping Human Brain Function with MEG and EEG: Methods and Validation. NeuroImage 23, 289-299. doi:10.1016/j.neuroimage.2004.07.014

De Lussanet, M. H. E., and Osse, J. W. M. (2012). An Ancestral Axial Twist Explains the Contralateral Forebrain and the Optic Chiasm in Vertebrates. Anim. Biol 62 (2), 193-216. doi:10.1163/157075611X617102

Dekker, S., Lee, N. C., Howard-Jones, P., and Jolles, J. (2012). Neuromyths in Education: Prevalence and Predictors of Misconceptions Among Teachers. Front. Psychol. 3, 1-8. doi:10.3389/fpsyg.2012.00429

Deligiannidi, K., and Howard-Jones, P. A. (2015). The Neuroscience Literacy of Teachers in Greece. Proced. - Soc. Behav. Sci. 174, 3909-3915. doi:10.1016/ j.sbspro.2015.01.1133

Doyle, T., and Zakrajsek, T. (2013). The New Science of Learning: How to Learn in harmony with Your Brain. Sterling, Virginia: Stylus Pub.

Dündar, S., and Gündüz, N. (2016). Misconceptions Regarding the Brain: The Neuromyths of Preservice Teachers. Mind, Brain Edu. 10 (4), 212-232. doi:10.1111/mbe.12119

Düvel, N., Wolf, A., and Kopiez, R. (2017). Neuromyths in Music Education: Prevalence and Predictors of Misconceptions Among Teachers and Students. Front. Psychol. 8, 629. doi:10.3389/fpsyg.2017.00629 
Dunlosky, J., Rawson, K. A., Marsh, E. J., Nathan, M. J., and Willingham, D. T. (2013). Improving Students' Learning with Effective Learning Techniques. Psychol. Sci. Public Interest 14 (1), 4-58. doi:10.1177/1529100612453266

Falquez Torres, J. F., and Ocampo Alvarado, J. C. (2018). Del conocimiento científico al malentendido. Prevalencia de neuromitos en estudiantes ecuatorianos. Rieoei 78, 87-106. doi:10.35362/rie7813241

Ferrero, M., Garaizar, P., and Vadillo, M. A. (2016). Neuromyths in Education: Prevalence Among Spanish Teachers and an Exploration of Cross-Cultural Variation. Front. Hum. Neurosci. 10, 496. doi:10.3389/fnhum.2016.00496

Folta-Schoofs, K., and Ostermann, B. (2019). Neurodidaktik: Grundlagen für Studium und Praxis. Stuttgart: Verlag W. Kohlhammer.

Fuentes, A., and Risso, A. (2015). Evaluación de conocimientos y actitudes sobre neuromitos en futuros/as maestros/as. R. Est Inv Psico y Educ. 6, 193-198. doi:10.17979/reipe.2015.0.06.530

Gais, S., and Born, J. (2004). Declarative Memory Consolidation: Mechanisms Acting during Human Sleep. Learn. Mem. 11 (6), 679-685. doi:10.1101/lm.80504

Geake, J. (2008). Neuromythologies in Education. Educ. Res. 50 (2), 123-133. doi:10.1080/00131880802082518

Geerligs, L., Renken, R. J., Saliasi, E., Maurits, N. M., and Lorist, M. M. (2015). A Brain-wide Study of Age-Related Changes in Functional Connectivity. Cereb. Cortex 25 (7), 1987-1999. doi:10.1093/cercor/bhu012

Genç, E., Fraenz, C., Schlüter, C., Friedrich, P., Hossiep, R., Voelkle, M. C., et al. (2018). Diffusion Markers of Dendritic Density and Arborization in Gray Matter Predict Differences in Intelligence. Nat. Commun. 9, 1905. doi:10.1038/ s41467-018-04268-8

Gleichgerrcht, E., Lira Luttges, B., Salvarezza, F., and Campos, A. L. (2015). Educational Neuromyths Among Teachers in Latin America. Mind, Brain Edu. 9 (3), 170-178. doi:10.1111/mbe.12086

Grospietsch, F., and Mayer, J. (2018). Professionalizing Pre-service Biology Teachers' Misconceptions about Learning and the Brain through Conceptual Change. Edu. Sci. 8 (3), 120. doi:10.3390/educsci8030120

Grospietsch, F., and Mayer, J. (2019). Pre-service Science Teachers' Neuroscience Literacy: Neuromyths and a Professional Understanding of Learning and Memory. Front. Hum. Neurosci. 13, 20. doi:10.3389/fnhum.2019.00020

Grospietsch, F., and Mayer, J. (2020). Misconceptions about Neuroscience Prevalence and Persistence of Neuromyths in Education. Neuroforum 26 (2), 63-71. doi:10.1515/nf-2020-0006

Grospietsch, F., and Mayer, J. (2021a). Angebot, Nutzung und Ertrag von Konzeptwechseltexten zu Neuromythen bei angehenden Biologielehrkräften. ZfDN. doi:10.1007/s40573-021-00127-0

Grospietsch, F., and Mayer, J. (2021b). Didaktische Rekonstruktion als Planungsund Forschungsrahmen nutzen - Fachliche Klärung, Gestaltung und Evaluation einer universitären Lehrveranstaltung zum Thema Gehirn und Lernen. Herausforderung Lehrer*innenbildung - Zeitschrift zur Konzeption, Gestaltung und Diskussion 4 (2), 165-192. doi:10.11576/hlz-2548

Grospietsch, F. (2019). Berücksichtigung von Studierendenvorstellungen zum Thema Gehirn und Lernen in der Lehrkräfteausbildung Biologie. Dissertation, Universität Kassel. doi:10.17170/kobra-202107164345

Grospietsch, F. (2021). Warum man Schülervorstellungen im Unterricht berücksichtigen sollte. Ein neurodidaktisches Plädoyer. MNU J. 2, 106-110.

Grube, D., and Ricken, G. (2016). "Rechenschwäche und Dyskalkulie," in Handbuch Schulpsychologie. Editors K. Seifried, S. Drewes, and M. Hasselhorn (Stuttgart: Verlag W. Kohlhammer), 208-218.

Gruber, T. (2018). Gedächtnis. 2nd edn. Berlin, Heidelberg: Springer. doi:10.1007/ 978-3-662-56362-5

Hattie, J. (2009). Visible Learning: A Synthesis of over 800 Meta-Analyses Relating to Achievement. New York: Routledge. doi:10.4324/9780203887332

Herculano-Houzel, S. (2002). Do You Know Your Brain? A Survey on Public Neuroscience Literacy at the Closing of the Decade of the Brain. Neuroscientist 8 (2), 98-110. doi:10.1177/107385840200800206

Hermida, M. J., Segretin, M. S., Soni García, A., and Lipina, S. J. (2016). Conceptions and Misconceptions about Neuroscience in Preschool Teachers: a Study from Argentina. Educ. Res. 58 (4), 457-472. doi:10.1080/00131881.2016.1238585

Hilgetag, C. C., and Barbas, H. (2009). Are There Ten Times More Glia Than Neurons in the Brain? Brain Struct. Funct. 213 (4-5), 365-366. doi:10.1007/ s00429-009-0202-z

Hines, T. (1991). The Myth of Right Hemisphere Creativity. J. Creat. Behav. 25, 3. doi:10.1002/j.2162-6057.1991.tb01373.x
Höffler, T. N., Koć-Januchta, M., and Leutner, D. (2017). More Evidence for Three Types of Cognitive Style: Validating the Object-Spatial Imagery and Verbal Questionnaire Using Eye Tracking when Learning with Texts and Pictures. Appl. Cognit. Psychol. 31 (1), 109-115. doi:10.1002/acp.3300

Horvath, J. C., Donoghue, G. M., Horton, A. J., Lodge, J. M., and Hattie, J. A. C. (2018). On the Irrelevance of Neuromyths to Teacher Effectiveness: Comparing Neuro-Literacy Levels Amongst Award-Winning and Non-award Winning Teachers. Front. Psychol. 9, 1666. doi:10.3389/fpsyg.2018.01666

Howard-Jones, P. A., Franey, L., Mashmoushi, R., and Liau, Y.-C. (2009). The Neuroscience Literacy of Trainee Teachers, Paper presented at the British Educational Research Association Annual Conference, Manchester.

Howard-Jones, P. (2010). Introducing Neuroeducational Research - Neuroscience, Education and the Brain from Contexts to Practice. New York: Routledge.

Howard-Jones, P. A. (2014). Neuroscience and Education: Myths and Messages. Nat. Rev. Neurosci. 15 (12), 817-824. doi:10.1038/nrn3817

Hyatt, K. J. (2007). Brain Gym ${ }^{\circledR}$ : Building stronger brains or wishful thinking? Remedial Spec. Edu. 28 (2), 117-124. doi:10.1177/07419325070280020201

Im, S.-h., Cho, J.-Y., Dubinsky, J. M., and Varma, S. (2018). Taking an Educational Psychology Course Improves Neuroscience Literacy but Does Not Reduce Belief in Neuromyths. Plos One 13 (2), e0192163. doi:10.1371/ journal.pone. 0192163

Jäncke, L. (2013). Lehrbuch Kognitive Neurowissenschaften. Milwaukee, WI: Hans Huber.

Janati Idrissi, A., Alami, M., Lamkaddem, A., and Souirti, Z. (2020). Brain Knowledge and Predictors of Neuromyths Among Teachers in Morocco. Trends Neurosci. Edu. 20, 100135. doi:10.1016/j.tine.2020.100135

Jarrett, C. (2014). Great Myths of the Brain. New York: John Wiley \& Sons.

Jensen, E. (1998). Teaching with the Brain in Mind. Alexandria: Association for Supervision and Curriculum Development.

Jensen, E. (2008). Brain-Based Learning: The New Paradigm of Teaching. 2nd edn. Thousand Oaks: Corwin Press. doi:10.4135/9781506321660

Kagan, S. (2014). Brain-friendly Teaching: Tools, Tips \& Structures. San Clemente, CA: Kagan Publishing. doi:10.4324/9781315044033

Karakus, O., Howard-Jones, P. A., and Jay, T. (2015). Primary and Secondary School Teachers' Knowledge and Misconceptions about the Brain in Turkey. Proced. - Soc. Behav. Sci. 174, 1933-1940. doi:10.1016/j.sbspro.2015.01.858

Kattmann, U., Duit, R., Gropengießer, H., and Komorek, M. (1997). Das Modell der Didaktischen Rekonstruktion - Ein Rahmen für naturwissenschaftsdidaktische Forschung und Entwicklung. ZfDN 3 (3), 3-18.

Kim, M., and Sankey, D. (2017). Philosophy, Neuroscience and Pre-service Teachers' Beliefs in Neuromyths: A Call for Remedial Action. Educ. Philos. Theory 50 (13), 1214-1227. doi:10.1080/00131857.2017.1395736

Kinsbourne, M. (2013). Somatic Twist: A Model for the Evolution of Decussation. Neuropsychology 27 (5), 511-515. doi:10.1037/a0033662

Krammer, G., Vogel, S. E., Yardimci, T., and Grabner, R. H. (2019). Neuromythen sind zu Beginn des Lehramtsstudiums prävalent und unabhängig vom Wissen über das menschliche Gehirn. Z. f. Bildungsforsch. 9, 221-246. doi:10.1007/ s35834-019-00238-2

Krammer, G., Vogel, S. E., and Grabner, R. H. (2020). Believing in Neuromyths Makes Neither a Bad Nor Good Student-Teacher: The Relationship between Neuromyths and Academic Achievement in Teacher Education. Mind Brain Educ. 15 (1), 54-60. doi:10.1111/mbe.12266

Lai, V. T., van Dam, W., Conant, L. L., Binder, J. R., and Desai, R. H. (2015). Familiarity Differentially Affects Right Hemisphere Contributions to Processing Metaphors and Literals. Front. Hum. Neurosci. 9, 44. doi:10.3389/fnhum.2015.00044

LeDoux, J. (2007). The Amygdala. Curr. Biol. 17 (20), R868-R874. doi:10.1016/ j.cub.2007.08.005

Lethaby, C., and Harries, P. (2016). Learning Styles and Teacher Training: Are We Perpetuating Neuromyths? ELT J. 70 (1), 16-27. doi:10.1093/elt/ccv051

Lilienfeld, S. O., Lynn, S. J., Ruscio, J., and Beyerstein, B. L. (2010). 50 Great Myths of Popular Psychology: Shattering Widespread Misconceptions about Human Behavior. Hoboken: John Wiley \& Sons.

Lindell, A. K., and Kidd, E. (2011). Why Right-Brain Teaching Is Half-Witted: A Critique of the Misapplication of Neuroscience to Education. Mind Brain Educ. 5 (3), 121-127. doi:10.1111/j.1751-228X.2011.01120.x

Lipowsky, F., Richter, T., Borromeo-Ferri, R., Ebersbach, M., and Hänze, M. (2015). Wünschenswerte Erschwernisse Beim Lernen. Schulpädagogik Heute. $6(11)$. 
Looß, M. (2001). Lerntypen? Ein pädagogisches Konstrukt auf dem Prüfstand. Die deutsche Schule 2, 186-198.

Macdonald, K., Germine, L., Anderson, A., Christodoulou, J., and McGrath, L. M. (2017). Dispelling the Myth: Training in Education or Neuroscience Decreases but Does Not Eliminate Beliefs in Neuromyths. Front. Psychol. 8, 1314. doi:10.3389/fpsyg.2017.01314

Mayfield, K. H., and Chase, P. N. (2002). The Effects of Cumulative Practice on Mathematics Problem Solving. J. Appl. Behav. Anal. 35, 105-123. doi:10.1901/ jaba.2002.35-105

McCarthy, M. A., and Frantz, S. (2016). "Challenging the Status Quo: Evidence that Introductory Psychology can Dispel Myths.” Teach. Psychol. 43 (3), 211-214. doi:10.1177/0098628316649470

McComas, W. F. (1998). The Nature of Science in Science Education - Rationales and Strategies. Dordrecht: Kluwer Academic Publishers.

McMahon, K., Yeh, C. S. H., and Etchells, P. J. (2019). The Impact of a Modified Initial Teacher Education on Challenging Trainees' Understanding of Neuromyths. Mind, Brain Edu. 13 (4), 288-297. doi:10.1111/mbe.12219

Meinhardt, J. (2019). "Gehirn und Lernen," in Psychologie für den Lehrberuf. Editors D. Urhahne, M. Dresel, and F. Fischer (Berlin, Heidelberg: Springer), 85-106. doi:10.1007/978-3-662-55754-9_5

Menz, C., Spinath, B., and Seifried, E. (2020). Misconceptions Die Hard: Prevalence and Reduction of Wrong Beliefs in Topics from Educational Psychology Among Preservice Teachers. Eur. J. Psychol. Educ. 36, 477-494. doi:10.1007/s10212-02000474-5

Menz, C., Spinath, B., Hendriks, F., and Seifried, E. (2021a). Reducing Educational Psychological Misconceptions: How Effective Are Standard Lectures, Refutation Lectures, and Instruction in Information Evaluation Strategies? Scholarship Teach. Learn. Psychol, 1-20. doi:10.1037/stl0000269

Menz, C., Spinath, B., and Seifried, E. (2021b). Where Do Pre-service Teachers' Educational Psychological Misconceptions Come from? Z. f. Pädagogische Psychol. 35 (2-3), 143-156. doi:10.1024/1010-0652/a000299

Muzet, A. (2007). Environmental Noise, Sleep and Health. Sleep Med. Rev. 11 (2), 135-142. doi:10.1016/j.smrv.2006.09.001

Newton, P. M., and Miah, M. (2017). Evidence-Based Higher Education - Is the Learning Styles 'Myth' Important? Front. Psychol. 8, 444. doi:10.3389/ fpsyg.2017.00444

Newton, P. M., and Salvi, A. (2020). How Common Is Belief in the Learning Styles Neuromyth, and Does it Matter? A Pragmatic Systematic Review. Front. Educ. 5. doi:10.3389/feduc. 2020.602451

Newton, P. M. (2015). The Learning Styles Myth Is Thriving in Higher Education. Front. Psychol. 6, 1908. doi:10.3389/fpsyg.2015.01908

Nielsen, J. A., Zielinski, B. A., Ferguson, M. A., Lainhart, J. E., and Anderson, J. S. (2013). An Evaluation of the Left-Brain vs. Right-Brain Hypothesis with Resting State Functional Connectivity Magnetic Resonance Imaging. Plos One 8 (8), e71275. doi:10.1371/journal.pone.0071275

Ocklenburg, S., Hirnstein, M., Beste, C., and Güntürkün, O. (2014). Lateralization and Cognitive Systems. Front. Psychol. 5. doi:10.3389/fpsyg.2014.01143

Organisation for Economic Co-operation and Development [OECD] (2002). Understanding the Brain: Towards a New Learning Science. Paris: OECD.

Organisation for Economic Co-operation and Development [OECD] (2005). Wie funktioniert das Gehirn? - Auf dem Weg zu einer neuen Lernwissenschaft. Stuttgart: Schatthauer.

Organisation for Economic Co-operation and Development [OECD] (2015). Neuromyth 1. Available at: https://www.oecd.org/education/ceri/neuromyth1. htm (Accessed May 7, 2021).

Papadatou-Pastou, M., Haliou, E., and Vlachos, F. (2017). Brain Knowledge and the Prevalence of Neuromyths Among Prospective Teachers in Greece. Front. Psychol. 8, 804. doi:10.3389/fpsyg.2017.00804

Papadatou-Pastou, M., Touloumakos, A. K., Koutouveli, C., and Barrable, A. (2020). The Learning Styles Neuromyth: when the Same Term Means Different Things to Different Teachers. Eur. J. Psychol. Educ. 36, 511-531. doi:10.1007/ s10212-020-00485-2

Papatzikis, E. (2017). Neuromyths in Education and Development: A Comprehensive Approach. Eur. Scientific J. 13 (3), 85-91.

Pashler, H., McDaniel, M., Rohrer, D., and Bjork, R. (2008). Learning styles: Concepts and Evidence. Psychol. Sci. Public Interest 9 (3), 105-119. doi:10.1111/j.15396053.2009.01038.x
Pasquinelli, E. (2012). Neuromyths: Why Do They Exist and Persist? Mind Brain Educ. 6, 89-96. doi:10.1111/j.1751-228x.2012.01141.x

Pei, X., Howard-Jones, P. A., Zhang, S., Liu, X., and Jin, Y. (2015). Teachers' Understanding about the Brain in East China. Proced. - Soc. Behav. Sci. 174, 3681-3688. doi:10.1016/j.sbspro.2015.01.1091

Perani, D., Saccuman, M. C., Scifo, P., Spada, D., Andreolli, G., Rovelli, R., et al. (2010). Functional Specializations for Music Processing in the Human Newborn Brain. Proc. Natl. Acad. Sci. 107, 4758-4763. doi:10.1073/ pnas. 0909074107

Petitto, L.-A., and Dunbar, K. (2004). "New Findings from Educational Neuroscience on Bilingual Brains, Scientific Brains, and the Educated Mind," in Building Usable Knowledge in Mind, Brain, \& Education. Editors K. Fischer and T. Katzir (Cambridge, MA: Cambridge University Press).

Purdy, N. (2008). Neuroscience and Education: How Best to Filter Out the Neurononsense from Our Classrooms? Irish Educ. Stud. 27 (3), 197-208. doi:10.1080/03323310802242120

Rato, J. R., Abreu, A. M., and Castro-Caldas, A. (2013). Neuromyths in Education: what Is Fact and what Is Fiction for Portuguese Teachers? Educ. Res. 55 (4), 441-453. doi:10.1080/00131881.2013.844947

Rohrer, D., and Taylor, K. (2007). The Shuffling of Mathematics Problems Improves Learning. Instr. Sci. 35 (6), 481-498. doi:10.1007/s11251-0079015-8

Rousseau, L., and Brabant-Beaulieu, J. (2020). Le neuromythe des "styles d'apprentissage "VAK (visuel, auditif, kinesthésique): une tentative de démystification auprès d'apprentis enseignants franco-ontariens. Neuroed. 6 (1), 65-91. doi:10.24046/neuroed.20200601.37

Rousseau, L. (2020). Let's Scrap the Neuromyths: No, You Aren't a 'visual' or 'auditory' Person. Available at: https://theconversation.com/lets-scrap-theneuromyths-no-you-arent-a-visual-or-auditory-person-141957 (Accessed May 11, 2021)

Ruhaak, A. E., and Cook, B. G. (2018). The Prevalence of Educational Neuromyths Among Pre-Service Special Education Teachers. Mind, Brain Edu. 12 (3). doi:10.1111/mbe.12181

Schaal, S. (2018). Faszination: Mythos. Konzepte zum Aufbau eines kritischen Wissenschaftsverständnisses. Unterricht Biologie 42 (431), 2-10.

Schletter, J. C., and Bayrhuber, H. (1998). Lernen und Gedächtnis Kompartimentalisierung von Schülervorstellungen und wissenschaftlichen Konzepten. ZfDN 4 (3), 19-34.

Simmonds, A. (2014). How Neuroscience Is Affecting Education: Report of Teacher and Parent Survey. Available at: https://wellcome.ac.uk/sites/default/files/ wtp055240.pdf (Accessed October 5, 2018).

Singh, H., and O'Boyle, M. W. (2004). Interhemispheric Interaction during GlobalLocal Processing in Mathematically Gifted Adolescents, Average-Ability Youth, and College Students. Neuropsychology 18 (2), 371-377. doi:10.1037/08944105.18.2.371

Škraban, O. P., Vituli'c, H. S., Tancig, S., and Prosen, S. (2018). Neuromyths about Brain Development and Learning Among university Students of Primary Education. Didact. Sloven Pedag Obz 33, 136-148.

Spear, L. P. (2013). Adolescent Neurodevelopment. J. Adolesc. Health 52 (2), S7-S13. doi:10.1016/j.jadohealth.2012.05.006

Sprenger, M. B. (2002). Becoming a "Wiz" at Brain-Based Teaching. Thousand Oaks, CA: Corwin Press, Inc.

Stephenson, J. (2009). Best Practice? Advice Provided to Teachers about the Use of Brain Gym $^{\circledR}$ in Australian Schools. Aust. J. Edu. 53 (2), 109-124. doi:10.1177/ 000494410905300202

Stickgold, R. (2012). To Sleep: Perchance to Learn. Nat. Neurosci. 15 (10), 1322-1323. doi:10.1038/nn.3223

Tardif, E., Doudin, P.-A., and Meylan, N. (2015). Neuromyths Among Teachers and Student Teachers. Mind, Brain Edu. 9, 50-59. doi:10.1111/ mbe. 12070

Thomas, M. S. C., and Johnson, M. H. (2008). New Advances in Understanding Sensitive Periods in Brain Development. Curr. Dir. Psychol. Sci. 17 (1), 1-5. doi:10.1111/j.1467-8721.2008.00537.x

Tokuhama-Espinosa, T. (2018). Neuromyths: Debunking False Ideas about the Brain. New York: W. W. Norton \& Company.

Torrijos-Muelas, M., González-Víllora, S., and Bodoque-Osma, A. R. (2021). The Persistence of Neuromyths in the Educational Settings: A Systematic Review. Front. Psychol. 11, 591923. doi:10.3389/fpsyg.2020.591923 
Tovazzi, A., Giovannini, S., and Basso, D. (2020). A New Method for Evaluating Knowledge, Beliefs, and Neuromyths About the Mind and Brain Among Italian Teachers. Mind, Brain Edu. 14 (2), 187-198. doi:10.1111/ mbe. 12249

van Dijk, W., and Lane, H. B. (2018). The Brain and the US Education System: Perpetuation of Neuromyths. Exceptionality 28 (1), 16-29. doi:10.1080/ 09362835.2018.1480954

Varas-Genestier, P., and Ferreira, R. A. (2017). Neuromitos de los profesores chilenos: orígenes y predictores. Estud. Pedagóg. 43, 341-360. doi:10.4067/ S0718-07052017000300020

Vester, F. (1975). Denken, Lernen, Vergessen: was geht in unserem Kopf vor, wie lernt das Gehirn, und wann lässt es uns im Stich? Stuttgart: Deutsche VerlagsAnstalt.

von Bartheld, C. S., Bahney, J., and Herculano-Houzel, S. (2016). The Search for True Numbers of Neurons and Glial Cells in the Human Brain: A Review of 150 Years of Cell Counting. J. Comp. Neurol. 524 (18), 3865-3895. doi:10.1002/cne.24040

Whittingstall, K., and Logothetis, N. K. (2009). Frequency-Band Coupling in Surface EEG Reflects Spiking Activity in Monkey Visual Cortex. Neuron 64 (2), 281-289. doi:10.1016/j.neuron.2009.08.016

Willcutt, E. G., Petrill, S. A., WuBoada, S. R., Boada, R., DeFries, J. C., Olson, R. K., et al. (2013). Comorbidity Between Reading Disability and Math Disability: Concurrent Psychopathology, Functional Impairment, and Neuropsychological Functioning. J. Learn. Disabil. 46 (6), 500-516. doi:10.1177/0022219413477476
Willingham, D. T., Hughes, E. M., and Dobolyi, D. G. (2015). The Scientific Status of Learning Styles Theories. Teach. Psychol. 42 (3), 266-271. doi:10.1177/ 0098628315589505

Zhang, R., Jiang, Y., Dang, B., and Zhou, A. (2019). Neuromyths in Chinese Classrooms: Evidence from Headmasters in an Underdeveloped Region of China. Front. Educ. 4, 8. doi:10.3389/feduc.2019.00008

Zheng, P., Dimitrakakis, C., and Triesch, J. (2013). Network Self-Organization Explains the Statistics and Dynamics of Synaptic Connection Strengths in Cortex. Plos Comput. Biol. 9 (1), e1002848-9. doi:10.1371/ journal.pcbi.1002848

Ziegler, E., and Stern, E. (2014). Delayed Benefits of Learning Elementary Algebraic Transformations through Contrasted Comparisons. Learn Instruct. 33, 131-146. doi:10.1016/j.learninstruc.2014.04.006

Conflict of Interest: The authors declare that the research was conducted in the absence of any commercial or financial relationships that could be construed as a potential conflict of interest.

Copyright (c) 2021 Grospietsch and Lins. This is an open-access article distributed under the terms of the Creative Commons Attribution License (CC BY). The use, distribution or reproduction in other forums is permitted, provided the original author(s) and the copyright owner(s) are credited and that the original publication in this journal is cited, in accordance with accepted academic practice. No use, distribution or reproduction is permitted which does not comply with these terms. 